УДК 355.1-057.36(477.82);94(477)"2014/2018"

ДЕМ'ЯНЮК О.Й.

https://orcid.org/0000-0002-0034-5768

https://doi.org/10.33577/2313-5603.34.2020.200-212

\title{
ЛЕТАЛЬНІ ВТРАТИ ВОЛИНЯН ПІД ЧАС ПРОВЕДЕННЯ АНТИТЕРОРИСТИЧНОЇ ОПЕРАЦІЇ НА СХОДІ УКРАЇНИ (2014 - 2018)
}

У період, коли Україна продовжує боротися за територіальну цілісність, коли на Сході Держави бойові зіткнення чергуються з недовготривалою тишею, перегляду й переосмисленню підлягають всі роки новітньої незалежності, роки становлення Української державності на предмет нашої національної самодостатності. Задля цього українці кладуть голови у боротьбі з проросійськими сепаратистами. За час проведення антитерористичної операції на сході України двісті вісімнадцять волинян стали жертвами збройного протистояння. Маємо пам'ятати про героїв, які віддали своє життя за територіальну цілісність України. Про цих вояків, їх жертовність й мужність йде мова у статті. Аналізу піддано обставини їх загибелі, починаючи від трагедії під Волновахою, динаміку смертності серед волинян-військовослужбовців упродовж 2014 - початку 2018 рр., тенденцію до збільшення кількості небойових втрат.

Ключові слова: Збройні Сили України, Антитерористична операція, російськоукраїнська війна, Волинь, Волинська область, військовослужбовець, державний суверенітет, бойові / небойові втрати.

Постановка проблеми та ї̈ актуальність. На завершальному етапі Революції Гідності почали наростати сепаратистські настрої на Півдні та Сході України. Після вдалої анексії Кримської автономії Росією прокремлівські сили від квітня 2014 p. розпочали розпалювати міжнаціональну ворожнечу на територіях південно-східних областей України. Порушити територіальну цілісність України цим силам вдалося на частині Донецької та Луганської областей. Невдовзі тут дійшло до кривавого протистояння незаконних збройних формувань, підтриманих, озброєних й керованих 3 території Російської Федерації 3 правоохоронними органами України, з наступним залученням військових підрозділів Збройних Сил України. Сепаратистські збройні формування, а фактично - терористичні організації, дестабілізували ситуацію в цій частині держави й розпочали захоплення населених пунктів Південно-Східної України.

Дем'янюк Олександр Йосипович, доктор історичних наук, професор, проректор з науково-педагогічної роботи та моніторингу якості освіти Волинського інституту післядипломної педагогічної освіти, м. Луцьк.

() Дем'янюк О.Й., 2020 
Під загрозою відкритої агресії Росії та значних територіальних втрат політичне керівництво держави оголосило Антитерористичну операцію (АТО) на території цих областей із залученням Збройних Сил України. Нею охоплено Донецьку і Луганську області (з 14 квітня 2014 р.), Ізюмський район та м. Ізюм Харківської області (14 квітня - 7 вересня 2014 р.) (Про боротьбу з тероризмом: Закон України, 2003). 30 квітня 2018 р. АТО було змінено на операцію Об'єднаних сил (ООС).

Натомість в Україні з'явилися розвідувально-диверсійні групи російських збройних сил, а локальне протистояння поступово переросло у масштабний воєнний конфлікт. В Україні було оголошено мобілізацію. Фактично відтоді й розпочалася неоголошена війна з Росією.

На виконання плану мобілізації у Волинській області відповідні заходи розпочалися 8-9 квітня 2014 р. Жителі Волинського краю почали брати активну участь у захисті державного суверенітету й територіальної цілісності на Сході країни. Більшість мобілізованих волинян у 2014 р. поповнили лави 51-ї окремої механізованої бригади (51-ї омбр), яка дислокувалася в місті Володимир-Волинський Волинської області. Від грудня 2014 р. на базі цієї військової частини було створено 14-ту окрему механізовану бригаду (14-ту омбр).

Майже відразу Волинський край розпочав свій рахунок у цій війні. Від початку російської агресії на Сході України сотні волинян пішли добровольцями боронити Батьківщину, сотні чоловіків мобілізували до лав Українського війська. Відтоді Волинь за час проведення АТО втратила понад дві сотні Героїв, понад дві сотні разів область перебувала у жалобі - волиняни ховали своїх земляків (110 волинян загинуло й померло у 2014 р., 65 - у 2015 р., 29 - у 2016 р., 13 - у 2017 р., 1 - до 30 квітня 2018 р.).

Аналіз попередніх досліджень $і$ публікацій. Підбираючи матеріал для написання статті, з'ясовано, що вивчення цієї проблеми має наукову доцільність, позаяк обрана тема жодного разу не ставала предметом грунтовного наукового дискурсу. Створюючи загальну картину жертовності волинян-військовиків, що загинули на Сході України, аналізуючи та узагальнюючи опрацьований матеріал, послуговувалися працями волинських дослідників О. Дем'янюка та Г. Гулька (подають перелік загиблих і померлих волинян у 2014 - 2017 рр.) (2018), статтями в місцевій періодиці, електронних 3МI. 
Мета та завдання дослідження. Узагальнимо відомості про загиблих / померлих волинян у період проведення Антитерористичної операції на сході України (2014 - квітень 2018 рр.), з'ясуємо обставини летальних втрат, виокремимо причини бойових / небойових втрат.

Виклад основного матеріалу дослідження. Насамперед зазначимо, що нас, у розрізі проблеми дослідження, цікавитиме період від середини квітня 2014 р. до кінця квітня 2018 р., тобто той відтинок часу, коли тривала Антитерористична операція.

Уже вдосвіта 22 травня 2014 р. бійці 51-ї омбр були атаковані на блокпосту поблизу м. Волноваха на Донеччині. Блокпост упритул обстріляли терористи, які під’іххали на кількох джипах та інкасаторських машинах. Відразу на місці нападу загинуло дев'ять осіб. Згодом ще кілька військових померло в лікарнях від отриманих поранень. У результаті обстрілу десять волинян зі складу 3-го батальйону 51-ї омбр, у тому числі його командир майор Л. Полінкевич, загинули. Це були перші волинські втрати на Сході Держави. Назвемо поіменно загиблих бійців: майор Леонід Полінкевич, старший сержант Олександр Артемук, молодший сержант Дмитро Йовзик, солдати Микола Бондарук, Михайло Грицюк, Володимир Зарадюк, Віталій Ліщук, Віталій Махновець, Павло Попов, Володимир Прокопчук (Дем'янюк, Гулько, 2018).

Втрати Збройних Сил України у бою під Волновахою стали найбільшими від початку АТО та найбільшими, на той час, за новітню історію Української армії. Тут, у результаті нападу загинули 18 військовослужбовців 51-ї омбр. 29 травня бригаду виведено з зони АТО, однак вже 10 червня стало відомо, що підрозділи бригади повернуто в зону бойових дій.

14 березня 2015 р. на околиці Волновахи встановлено пам'ятний хрест загиблим українським бійцям. Він став першим пам'ятником українцям, полеглим у 2014 р. на Сході країни. 4 червня 2015 р. Президент України П. Порошенко підписав Указ про нагородження медаллю «Захиснику Вітчизни» за особисту мужність і високий професіоналізм, виявлені у захисті державного суверенітету та територіальної цілісності України, вірність Військовій присязі (Указ Президента Украӥни: Про відзначення державними нагородами Украӥни. 2015), усіх полеглих під Волновахою волинян. 
18 червня 2014 р. на околиці Станиці Луганської танк Т-64Б у складі командира танка молодшого сержанта Володимира Крохмаля і водія-механіка солдата Івана Ващені потрапив в оточення терористів. Снайпери противника розбили приціли i перископи. Перед тим як були розбиті прилади командира танка, він встиг помітити гранатометників, що ховались неподалік. Екіпаж встиг зробити постріли у бік ворога, але не влучив. Щоб не віддати бойову машину в руки сепаратистам і не здаватися у полон, екіпаж прийняв рішення підірвати танк (Власюк, 2014).

Улітку 2014 р. бої розгорнулися за курган Савур-Могила (Шахтарський район Донецької області). У різних військових підрозділах перебували тут волиняни. П'ятеро з них загинули, понад три десятки отримали поранення різного ступеня важкості. Так, 28 липня майор Віктор Хмелецький загинув під час мінометного обстрілу колони військових, яка пересувалася в район Савур-Могили. Старші солдати Володимир Поліщук і Олександр Свинчук загинули 5 серпня 2014 р. під час пошуково-ударних дій підрозділів 51-ї омбр (Романчук, 2014). Важкопоранений в бою за Савур-Могилу лучанин старший солдат Артем Карабан помер по дорозі в госпіталь Амвросіївки. 24 серпня солдат Петро Сусваль був важко поранений в бою за висоту Савур-Могила, помер 2 вересня 2014 р. в госпіталі.

У другій половині серпня 2014 р. бойові дії розгорнулися поблизу Іловайська. Після введення регулярних російських військ 23-24 серпня іловайське угруповання опинилося в потрійному оточенні. 29 серпня терористи погодилися випустити українських бійців з оточення. Однак колони підступно розстріляли, завдавши значних втрат особовому складу ЗСУ.

Не оминула іловайська бійня 51-шу омбр й інші підрозділи, в яких воювали волиняни. Так, за останніми підрахунками (на жаль, ще й донині залишаються пропалі безвісти волиняни, які виходили 3 іловайського котла) тридцять шість жителів Волинської області загинули в боях за Іловайськ, навколишні населені пункти і під час виходу з оточення через зелений коридор, який для них перетворився на кривавий.

Поблизу смт Кутейникове в ніч проти 25 серпня 2014 р. загинули бійці третього батальйону 51 омбр: майор Олексій Шепелюк, капітан Анатолій Шилік, старший лейтенант Віктор Михальчук, молодший сержант Дмитро Брик, старший солдат 
Леонід Крупець, солдати Сергій Бугайчук, Роман Данилевич, Андрій Мостика, Юрій Оніщук, Микола Павляшик. У бою за Іловайськ 25-28 серпня загинули: сержант Олександр Ярмолюк, старший солдат Олександр Войчук, солдати Роман Лучук, Ігор Пугач. Під час виходу 3 оточення під Іловайськом загинули військовослужбовці 51 омбр: старший прапорщик Сергій Смірнов, молодші сержанти Олександр Василюк, Сергій Дем'яник, В'ячеслав Іонов, молодший сержант запасу Іван Ганя, старші солдати Андрій Посполітак, Олексій Тарасюк, солдати Сергій Засєкін, Василь Зелінський (Дем'янюк, Гулько, 2018).

Переважна більшість особового складу роти патрульної служби міліції особливого призначення «Світязь» УМВС України у Волинській області організовано відступила 3-під Іловайська. Одинадцять бійців вийшли 3 оточення самотужки, семеро загинули в іловайському котлі: лейтенант міліції Максим Ляшук, сержант міліції Віктор Шолуха, рядові міліції Володимир Іщук, Сергій Помінкевич, Олександр Сацюк, Олександр Сивий, Мирослав Столярчук (Козюnа, 2014).

Ігор Філіпчук від початку бойових дій на Сході Держави записався добровольцем у батальйон «Айдар». Солдат І. Філіпчук загинув у бою біля селища Хрящувате Луганської області. Він тричі виходив із укриття, щоб вистрілити з ручного протитанкового гранатомета. На третій раз вже пошкоджений танк вистрілив у відповідь... Боєць зробив неможливе - він захистив своїх побратимів, захистив позиції i захистив честь українського добровольця (Моклиия, 2014).

У 2015 р. під час жорстоких боїв із сепаратистами, внаслідок влаштованих ними засідок, на «розтяжках» загинули або ж померли від ран, хвороб у шпиталях 45 волинян. Ще 20 учасників АТО померли від незалікованих ран, хвороб або ж загинули з інших причин невдовзі після повернення із зони бойових дій. На відміну від 2014 року, цьогоріч не було одночасної загибелі відразу кількох осіб. Адже наступальні операції майже не проводилися. Це пояснює як зменшення кількості загиблих, так і причини смертей. Принагідно згадаємо про окремих загиблих у 2015 р. волинян.

Відразу троє волинян, військовослужбовців 81-ї окремої аеромобільної бригади (оамбр), загинуло 3 квітня 2015 р. У складі бойової розвідувальної групи капітан Юрій Чучалін і 
солдат Андрій Карпюк, повертаючись у розташування свого підрозділу, підірвалися на «розтяжці» поблизу м. Авдіївка Донецької області. Односельчанин А. Карпюка солдат Дмитро Степанов підірвався на міні, намагаючись надати допомогу бійцям розвідувальної групи (Хітько, 2015).

Начальник державної виконавчої служби Рожищенського району Волинської області Іван Сотнік у вересні 2014 р. пішов добровольцем в зону АТО. Після військового вишколу воював у складі 2-го батальйону спеціального призначення НГУ «Донбас», де був командиром взводу. 2 травня 2015 р. в бою з російськими солдатами, обороняючи с. Широкине Новоазовського району Донецької області, молодший сержант I. Сотнік був поранений снайпером у голову (куля пробила каску). Помер у маріупольській лікарні під час другої операції (Дем'янюк, Гулько, 2018:180).

Трагічною виявилася доля багатьох волинян, захисників Донецького аеропорту. Так, солдат 3-го батальйону 80-ї аеромобільної бригади Олександр Грошев зник безвісти 20 січня 2015 р. під час боїв за Донецький аеропорт. Упізнаний за експертизою ДНК серед загиблих під руїнами стіни будівлі аеропорту в червні 2015 р. Солдат Василь Смолярчук зник безвісти під час оборони Донецького аеропорту. Як виявилося пізніше, він був серед загиблих під завалами нового терміналу, підірваного російськими бойовиками. Ідентифікований за експертизою ДНК лише навесні 2015 р.

14 січня 2015 р. 7-ма рота батальйону, в якому служив сержант Вадим Демчук, опинилася в повному оточенні в районі Донецького аеропорту. Тоді В. Демчук разом із двадцятьма двома десантниками, з боєм прорвалися до своїх побратимів на допомогу. Після тижневої оборони нового терміналу 20 січня 2015 р. сержант пропав безвісти. Тіло воїна, яке витягли з-під руїн аеропорту, довгий час перебувало у бойовиків. У червні передане у Дніпропетровськ, де, за експертизою ДНК, ідентифіковане (Дем'янюк, Гулько, 2018:55).

Особливістю 2016 р. були триваючі позиційні бойові дії в зоні АТО. Відтак різко зросла чисельність небойових втрат у військових частинах і поза їх межами. Серед воїнів-волинян зафіксовано сім таких фактів. Ще однією болючою темою для громадськості Волині стали факти раптових смертей, переважно від хвороб серця, нещодавно мобілізованих чи волинян-контрактників. У 2016 р. таких випадків було зафіксовано чотири. 
Так, 4 лютого, перебуваючи на навчальних зборах на Яворівському полігоні, від зупинки серця помер сержантконтрактник Олександр Бондар. 8 лютого після демобілізації від отриманої важкої побутової травми помер солдат Роман Остап’юк. Сержант Валентин Ремішко проходив лікування в госпіталях Миколаєва, Одеси, Луцька, Львова, де й помер 18 лютого 2016 р. внаслідок хвороби, одержаної під час проходження військової служби. 22 лютого 2016 р. від серцевої недостатності в пункті бойової дислокації підрозділу поблизу м. Мар'їнка Донецької області помер старший сержант Олег Вишневський (Дем'янюк, Гулько, 2018). 15 лютого загинув від смертельного поранення у пункті бойової дислокації військового підрозділу поблизу м. Артемівська Донецької області солдат Василь Шишолик (Бичкова, 2016).

Солдат Роман Луцюк 30 травня 2014 р. був зарахований до 24-го батальйону Територіальної оборони «Айдар». Після першого поранення, отриманого наприкінці липня 2014 р. під Георгіївкою на Луганщині, повернувся в зону бойових дій. 5 листопада цього ж року Р. Луцюк дістав важке поранення у живіт у районі м. Щастя на Луганщині. Спочатку лікувався у Київському військовому шпиталі, а від січня 2015 р. - у госпіталі в штаті Коннектикут (США). На жаль, лікарям не вдалося подолати наслідки важкого поранення. Вночі 20 березня 2016 р. він помер (Свереда, 2016).

Старшина Віктор Чопко мобілізований до лав 3СУ в четвертій хвилі мобілізації 4 лютого 2015 р. на посаду механіка-водія в 14-ту омбр. Загинув В. Чопко 25 березня 2016 р. від ураження осколками снаряда протитанкового гранатомета поблизу м. Мар’їнка Донецької області під час обстрілу одного з крайніх опорних пунктів 14-ї омбр (Кравчук, 2016). Старший солдат Олег Горкавчук у зону проведення АТО вперше прибув у складі «Айдару». 28 квітня 2015 р. призваний до лав ЗСУ за мобілізацією. Служив стрільцем у роті розвідки 128-ї окремої гірськопіхотної бригади (огпбр). Загинув у районі с. Піски Донецької області за нез'ясованих обставин.

Ще однієї бойової втрати Волинський край зазнав у листопаді 2016 р. Солдат Віктор Юхимчук 3 с. Щурин Рожищенського району у травні 2016 р. підписав контракт на службу в ЗСУ. Після підготовки й бойового вишколу воював вогнеметником вогнеметного взводу радіаційного, хімічного і бактеріологічного 
захисту 14-ї омбр. Загинув солдат В. Юхимчук 18 листопада під час виконання бойового завдання на спостережному посту поблизу смт Станиця Луганська Луганської області (Дем'янюк, Гулько, 2018:216).

Отож, у порівнянні з 2015 р. зросла кількість померлих вояківволинян від хвороб серця, контузій та поранень, отриманих під час бойових зіткнень на території Донецької і Луганської областей в зоні проведення АТО у перший рік після демобілізації.

Військове протистояння на Сході України в 2017 р. дещо відрізнялося від попереднього року й кардинально було іншим, ніж у 2014-2015 рр. Упродовж 2017 р. Українська армія здійснила низку вдалих військових операцій і встановила свій контроль над частиною територій так званої сірої зони. Насамперед це Світлодарська дуга, Горлівський периметр, Бахмутська траса. Продовжилося застосування тактики «повзучого наступу».

Бойові втрати серед волинян зменшилися. В 2017 р. гинули українські захисники внаслідок обстрілів із важкого озброєння, вогню снайперів, підривалися на мінах і розтяжках, а також під час бойових зіткнень 3 диверсійними групами супротивника. Безпосередньо на бойових позиціях у зоні АТО від куль та осколків загинуло шестеро волинян, ще четверо померли після демобілізації в шпиталях чи вдома від захворювань, одержаних під час проходження військової служби, в результаті нещасних випадків і побутових травм.

Бойових втрат Волинський край зазнав вже в січні 2017 p. 10 січня в результаті смертельного поранення у голову під час обстрілу позицій поблизу сіл Новозванівка - Троїцьке Попаснянського району Луганської області загинув гранатометник 1-го механізованого відділення 1-го механізованого батальйону 24-ої омбр імені князя Данила Галицького солдат Ігор Климюк. 12 січня в зоні бойових дій від снайперського кульового поранення під час обстрілу поблизу КПВВ «Станиця Луганська» на Луганщині загинув заступник командира бойової машини - навідник-оператор (БМП-1) 14-ї омбр старший солдат Богдан Корнелюк (Савчук, 2017).

У лютому бойові втрати серед волинян продовжилися. 3 лютого 2017 р. під час ворожого обстрілу з реактивної системи залпового вогню БМ-21 «Град» с. Галицинівка Мар'їнського району Донецької області загинув капітан Маріс Камінський. У 
зону проведення АТО Капітан М. Камінський прибув навесні 2014 р. у складі 3-ї батальйонної тактичної групи 80-ї одшбр. Пройшов кілька ротацій. Учасник оборони Луганського аеропорту. Наприкінці 2016 р. був призначений на посаду начальника продовольчої служби тилу 3-ї бтгр (Дем'янюк, Гулько, 2018:77).

19 лютого 2017 р. від кулі снайпера під час виконання бойового завдання в районі м. Авдіївка Донецької області загинув командир зенітно-ракетного взводу 1-го механізованого батальйону 72-ї омбр молодший лейтенант Максим Гринчишин (Лугова, 2017). До лав ЗСУ М. Гринчишин був мобілізований 14 серпня 2014 р. Бойовий шлях на Сході України розпочав під Волновахою кулеметником. Згодом отримав офіцерське звання, а посмертно став лейтенантом.

28 лютого 2017 р. внаслідок обстрілу зі 82-мм мінометів українських позицій на Світлодарській дузі, поблизу смт Луганське Бахмутського району Донецької області загинув солдат Сергій Мокренко. На Схід України волинянин вирушив у 2014 р. у складі ДУК «Правий сектор». Під час виходу 3-під Іловайська отримав множинні осколкові поранення. Після повернення додому майже рік займався волонтерством. У 2016 р. поїхав в полк «Азов» на навчання. Не дочекавшись офіційного оформлення в «Азові», С. Мокренко 14 вересня 2016 р. вступив на контрактну службу в 54-ту омбр стрільцем 3-ї роти 1-го батальйону (Дем'янюк, Гулько, 2018: 127).

У квітні 2017 р. від онкологічної хвороби помер старший прапорщик Олег Твердохліб. Від квітня 2014 р. він брав участь в бойових діях на території Луганської області в складі 24-го окремого штурмового батальйону «Айдар» на посадах старшини батальйону, командира взводу, заступника командира роти. 3 20 лютого 2015 р. призначений головним сержантом десантноштурмової роти 5-ї бтгр 81-ї десантно-штурмової бригади (дшбр). У жовтні 2015 р. звільнений у запас за станом здоров'я (в зоні АТО отримав 5 важких і 2 легких поранення). Обраний головою громадської організації «Спілка воїнів АТО Волині» (Дем'янюк, Гулько, 2018:189).

Старшина I статті Валерій Вашкевич 27 квітня 2014 р. був мобілізований Ківерцівським РВК до лав ЗСУ. Від 10 червня бійцем 2-го окремого мотопіхотного батальйону 30-ї омбр брав участь в бойових діях у зоні АТО (Козак, 2017:270). На 
Світлодарській дузі, внаслідок мінометного обстрілу отримав черепно-мозкову травму та контузію. 25 травня 2016 р. старшина I статті В. Вашкевич за станом здоров'я був демобілізований та скерований на обстеження й лікування в Луцький гарнізонний госпіталь. Після обстеження встановлено III групу інвалідності, підтверджено наслідки контузії. Лікування в медичних закладах Києва не дали позитивних результатів. Влітку 2017 р. здоров'я Валерія різко погіршилося, і 5 вересня він помер (Дем'янюк, Гулько, 2018:24).

2018 року на Сході України розпочалося перманентне загострення на фронті, в умовах спроб та протидії розведенню сил на певних ділянках бойового зіткнення, свідомого чи несвідомого «замороження» ситуації на території Донбасу. Врешті до 30 квітня було переглянуто низку військових i спеціальних організаційно-правових заходів, які здійснювали українські силові структури задля протидії діяльності незаконних збройних формувань на території Донецької та Луганської областей в умовах проведення АТО. Започатковано операцію Об'єднаних сил, а іï керівництво підпорядковане Об'єднаному оперативному штабу ЗСУ.

Ще до завершення періоду АТО, 15 квітня, під час несення служби на Луганщині помер старший солдат Анатолій Іллюх. Він служив за контрактом водієм-електриком 71-го маневреного центру радіоелектронної розвідки регіонального центру РЕР ОК «Захід». Від початку бойового протистояння на Сході України кілька разів відряджався в зону АТО (Пасічник, 2018).

Висновки. Таким чином, на час проведення Антитерористичної операції (14 квітня 2014 - 29 квітня 2018 рр.) загинуло / померло 218 волинян. Левова частка була військовослужбовцями 51-ї / 14-ї омбр (відповідно 76 / 20 осіб), 24-ї омбр - 16 вояків, 24-го батальйону Територіальної оборони «Айдар» - 14 бійців. Серед летальних втрат - 29 офіцерів. Посмертно нагороджено 141 волинянина: Герой України - 1, орден Богдана Хмельницького III ст. - 14, орден «За мужність» II ст. - 1, орден «За мужність» - 115, медаль «Захиснику Вітчизни» - 10 полеглих. Зведені причини загибелі / смерті волинян-військовослужбовців подаємо в таблиці: 


\begin{tabular}{|c|c|c|c|c|c|c|}
\hline & Причини & 2014 & 2015 & 2016 & 2017 & 2018 \\
\hline \multirow{2}{*}{$\begin{array}{l}\text { БОЙОВІ } \\
\text { ВТРАТИ } \\
\mathbf{( 1 6 3 )}\end{array}$} & $\begin{array}{l}\text { - загиблі під час бойо- } \\
\text { вого зіткнення з ворогом } \\
\text { і при виконанні бойо- } \\
\text { вих завдань в зоні прове- } \\
\text { дення Антитерористич- } \\
\text { ної операції }\end{array}$ & 110 & 29 & 5 & 6 & \\
\hline & $\begin{array}{l}\text { - військовослужбовці, } \\
\text { які підірвалися на мінах } \\
\text { і «розтяжках» на Сході } \\
\text { України }\end{array}$ & & 13 & & & \\
\hline \multirow{6}{*}{$\begin{array}{l}\text { НЕБОЙОВІ } \\
\text { ВТРАТИ } \\
\mathbf{( 5 5 )}\end{array}$} & $\begin{array}{l}\text { - небойові втрати в } \\
\text { зоні проведення опе- } \\
\text { рації АТО }\end{array}$ & & & 7 & 1 & 1 \\
\hline & $\begin{array}{l}\text { - померлі в госпіталях } \\
\text { чи під час лікування } \\
\text { від бойових ран чи } \\
\text { хвороб }\end{array}$ & & 6 & 4 & & \\
\hline & $\begin{array}{l}\text { - померлі на полігонах } \\
\text { під час навчань і бойо- } \\
\text { вого злагодження під- } \\
\text { розділів }\end{array}$ & & 1 & 3 & 1 & \\
\hline & $\begin{array}{l}\text { - померлі вдома під } \\
\text { час перебування у } \\
\text { відпустці }\end{array}$ & & 5 & & & \\
\hline & $\begin{array}{l}\text { - померлі в результаті } \\
\text { нещасних випадків }\end{array}$ & & 10 & & 1 & \\
\hline & $\begin{array}{l}\text { - померлі невдовзі після } \\
\text { демобілізації від захво- } \\
\text { рювань, одержаних під } \\
\text { час проходження війсь- } \\
\text { кової служби, в резуль- } \\
\text { таті нещасних випадків } \\
\text { і побутових травм }\end{array}$ & & 1 & 10 & 4 & \\
\hline & PA30M & 110 & 65 & 29 & 13 & 1 \\
\hline
\end{tabular}




\section{Використані посилання}

Бичкова О. (2016). Недоспівана пісня Василя Шишолика. Нова доба. 20 лютого.

Власюк Л. (2014). Підірвалися, щоб не здатися ворогу. Волинь-нова. 24 липня.

Дем'янюк О., Гулько Г. (2018). Волинський пантеон: Схід-2014-2017. Луцьк: Вежа-Друк. 246 с.

Козак Т. (2017). Старшина І статті Вашкевич Валерій Володимирович. Хай знову запахнуть житами поля. А в нас запанує хай мир. Бібліографічний довідник . Ч. ІІ. Луцьк : ФОП Л. В. Сікачова. С. 270-271.

Козюпа М. (2014). «Зелений» коридор став коридором смерті. Волинь-нова. 30 грудня.

Кравчук Н. (2016). Віктор Чопко загинув за кілька годин до оголошення демобілізації. Вісник+К. 31 березня.

Лугова М. (2017). Він віддав життя за Україну. Волинь-нова. 23 лютого.

Моклиця Ю. (2014). Ігор «Сороковий» Філіпчук - герой України, легенда «Айдару». Луизький замок. 21 серпня.

Пасічник I. (2018). I знову на Ковельщині сумно линуло «Пливе кача по Тисині...». Волинь-нова. 19 квітня.

Про боротьбу з тероризмом: Закон України № 638-IV від 20 березня 2003 року. (2003). Відомості Верховної Ради. № 25. С. 180.

Романчук Б. (2014). Ще три похоронки зі Сходу. Волинь-нова. 12 серпня.

Савчук В. (2017). «У цього хлопця була світла і вірна українська душа, і загинув він за Україну». Місто вечірне. 19 січня.

Свереда Т. (2016). Прожили коротко, але славно. Луцький замок. 31 березня.

Указ Президента України: Про відзначення державними нагородами України. № 311/2015 від 4 червня 2015 року. (2015). Доступно: https://zakon.rada .gov.ua/laws/show/311/2015\#Text. [Дата звернення 7 червня 2020].

Хітько М. (2015). Вони житимуть у наших серцях вічно. Вільним шляхом. 11 квітня.

\section{References}

Bychkova O. (2016). Unfinished song of Vasyl Shysholyk. New era. 20 February (ukr).

Vlasiuk L. (2014). Blew up in order not to surrender to the enemy. Volyn-nova. 24 July (ukr).

Demianiuk O., Hulko H. (2018). Volyn's pantheon: East-2014-2017. Lutsk: Vezha-Druk. p. 246 (ukr).

On fighting against terrorism (2003). Law of Ukraine No. 638-IV (ukr).

Kozak T. (2017). First-level sergeant-major Vashkevych Valerii Volodymyrovych. Let the fields smell with rye again. And let peace reign in us. Bibliography guide: Part II. Lutsk : Individual enterpreneur L. V. Sikachova. p. 270-271 (ukr).

Koziupa M. (2014). The green corridor became the death corridor. Volyn-nova. 30 December (ukr).

Kravchyk N. (2016). Viktor Chopko was killed a few hours befor demobilization was announced. Visnyk+K. 31 March (ukr).

Luhova M. (2017). He gave his life for Ukraine. Volyn-nova. 23 February (ukr). 
Moklytsia Yu. (2014). Ihor «the Fortieth» («sorokovyi») Filipchyk - hero of Ukraine, legend of «Aidar». Lutsk's castle. 21 August (ukr).

Pasichnyk I. 2018. And once more «The duck is swimming through Tysyna...» («Plyve kacha po Tysyni...») was sadly played in Kovel's area. Volyn-nova. 19 April (ukr).

Romanchuk B. 2014. Three more funeral letters from the East. Volyn-nova. 12 August (ukr).

Savchuk V. 2017. «This boy had a light and faithful Ukrainian soul, and he died for Ukraine». Evening town. 19 January (ukr).

Svereda T. 2016. They lived short but glorious life. Lutsk's castle. 31 March (ukr).

Order of the President of Ukraine On awarding with the state awards of Ukraine. No. 311/2015 (ukr).

Hitko M. 2015. They will live in our hearts forever. Free way. 11 April (ukr).

\section{Demianiuk O. \\ VOLYN RESIDENTS' FATAL LOSSES DURING THE ANTI-TERRORIST OPERATION IN EASTERN UKRAINE (2014 - 2018)}

At a time when Ukraine continues to fight for territorial integrity, and when combat actions in the east of the country alternate with short periods of silence, all the years of modern independence and the years of formation of Ukrainian statehood are subject to revision and rethinking from the perspective of our national selfsufficiency. For these purposes, Ukrainians bite the dust in the fight against proRussian separatists. During the anti-terrorist operation in eastern Ukraine, two hundred and eighteen Volynians became victims of armed confrontation. More than two hundred times Volyn region was in mourning - Volynians buried their compatriots (110 Volynians were killed or died in 2014, 65 - in 2015, 29 - in 2016, 13 - in 2017, and 1 up to 30 April 2018). We must remember the heroes who gave their lives for the territorial integrity of Ukraine. These soldiers, their sacrifice and courage are discussed in the article. The circumstances of their death, starting from the tragedy near Volnovakha, and the dynamics of mortality among Volyn's servicemen during 2014 - early 2018 were analyzed as well as the tendency for non-combat casualties number increase was explained. In addition, information about the Volynians who were killed or died during the anti-terrorist operation in eastern Ukraine (2014 - April 2018) is summarized, the circumstances of fatal losses are clarified, and the causes of combat / non-combat losses are singled out. It was calculated that most of the deceased Volyn residents were servicemen of the 51st / 14th Guards Mechanized Brigades (76 and 20 people, respectively), the 24th Guards Mechanized Brigade - 16 soldiers, and the 24th Aidar Territorial Guard Battalion - 14 soldiers. Among the fatal losses of the Volyn region 29 officers. 141 people from Volyn were posthumously awarded, while among them the highest award of the Hero of Ukraine was awarded to eighteen-year-old Andriy Snitko.

Keywords: Armed Forces of Ukraine, anti-terrorist operation, Russian-Ukrainian war, Volyn, Volyn region, military serviceman, state sovereignty, combat / noncombat losses. 